\title{
Spaces of Privacy in Early Modern Dutch Egodocuments*
}

\author{
Michaël Green
}

TSEG 18 (3) $17-40$

DOI: $10.52024 /$ tseg.11041

\begin{abstract}
While the word 'privacy' itself only started to appear in the Dutch language in the newspapers of the nineteenth-century, Michaël Green argues that the idea underlying it was already developing in the early seventeenth century in Dutch contexts. In his article, Green examines, first, transformations that occurred in the seventeenth century in architectural idealizations of the family house, where plans for corridors started to appear alongside locks and separate rooms. Then, based on several examples of egodocuments - among them the diaries of the schoolmaster David Beck and an autobiographical piece by Maria de Neufville - he focusses on how members of the middle and elite classes wrote about their own practical experiences of spatial and emotional privacy.
\end{abstract}

\section{Introduction}

The search for notions of privacy in written documents in the United Provinces of the Netherlands in the early modern period is difficult because people in the region, regardless of which dialect of the local languages they spoke, tended not to use any specific or particular word to describe the concept of privacy. In the Dutch context, the word 'privacy' - a word imported into the lexicon from English - was first used only in the first decade of the nineteenth century in newspapers in the Dutch East and West Indies. ${ }^{1}$ Since these colonies were occupied by England,

* I would like to thank Rudolf Dekker for his advice and support in preparation of this article and, in particular, of the introductory section. I would also like to thank the editor of this volume, Natália da Sil- 
their newspapers were published in English. ${ }^{2}$ In 1817 , the De Curaçaosche Courant used it in the context of 'The Nottingham Petition' to King George III (1738-1820): 'our intention is not to wound your feelings by prying into the secret recesses of your privacy'. ${ }^{3}$ Three years earlier, 'privacy' appeared in the Java Government Gazette: 'some persons who, having seen Mr. and Mrs. Goodall in the moments of domestic privacy, could have told how they lived together'. ${ }^{4}$ Shortly thereafter, 'privacy' began to appear in Dutch language newspapers in the colonies as an explanation of the Dutch word bedektheid. ${ }^{5}$ The first usage of this word (still within quotation marks ) in a Dutch language newspaper in the Netherlands occurred probably only in $1913 .{ }^{6}$ For several decades, the word 'privacy' was used as a loan word from English, printed 'as is' in Dutch texts; in fact, only recently has the word made an appearance in Dutch dictionaries. Today, 'privacy' is a fullyaccepted word in the Dutch language (similar to many other English words, such as 'hobby'), and its use in the Netherlands is similar to that in Britain, North America, and the rest of the world. Yet even though the word 'privacy' is not explicitly featured in early modern Dutch texts, does that necessarily mean that the idea or the concept of privacy was entirely absent from the minds of people in the early modern United Provinces? As Silva Perez's overview of the historiography has demonstrated in this volume, examples of people seeking privacy - defined as attempting to 'regulate access to

va Perez for her help in shaping this article. Finally, I would like to thank Ineke Huysman for her advice on my translations of the Dutch text into English. All translations unless otherwise stated are mine. This article was written with support from the Danish National Research Foundation grant DNRF 138 at the Centre for Privacy Studies, University of Copenhagen. It was accomplished during my research stay as CLUE+ fellow at the Vrije University of Amsterdam, and finalised at the University of Lodz. 'Privacy', Institute voor de Nederlandse taal, online ed., http://gtb.inl.nl/iWDB/search?actie=article\&wdb=WNT\&id=Ao12989\&lemmodern=privacy\&Betekenis_id=Ao12989.bet.1, accessed 3 June 2019.

1 The Oxford English Dictionary traces the provenance of the word 'privacy' in English all the way back to 1534 , noting that the word was even used by Shakespeare in 16o9. See 'Privacy', in: Oxford English Dictionary, online ed., https://www.oed.com/view/ Entry/151596?redirectedFrom=privacy, accessed 3 June 2019 .

3 De Curacaosche Courant 18 January (1817).

4 Java Government Gazette 14 May (1814).

5 'De bedektheid (privacy) die het geheele Engelsche leven kenmerkt, openbaart zich tot in het lommerdleven', De Locomotief 3 December (1884). This newspaper was published in Indonesia. 'Bedektheid' also means 'secrecy'.

6 'En bij de heterogoene gezelschappen, die deze pensions in het zeer internationale Berlijn gewoonlijk herbergen, is 'privacy' meer gewenscht nog dan elders'. See 'Berlijnsche Brieven', Provinciale Overijsselsche en Zwolsche Courant 8 March (1913) 4.

7 It is listed along with ' 526 . Latency, latiency, latitation, secrecy, secretness, privacy, invisibility' and '893. Seclusion, privacy, retirement, recess, retiredness, rustication'. See Peter Mark Roget, Thesaurus of English words \& phrases (New York 1878). 
oneself and to one's material or immaterial resources' - can be found throughout history and in different regions.

In this article, I show that such a notion was also present in the Dutch imagination in the early modern period, albeit expressed in different ways. I will focus on how people wrote about space - especially domestic space - as a defining aspect of how they attained privacy for themselves or even breached someone else's privacy . I start by discussing the ideas of Simon Stevin about the family home. Though his treatise De Huysbou presented the domestic space for an affluent member of society in a very idealized form, it does exemplify a (then emerging) concern in Dutch society with limiting accessibility to certain parts of the family house. Then, in the following sections, I will discuss how three individual authors of egodocuments represented in their personal writings their own understanding of private spaces. ${ }^{8}$ I will show how expressions of the need for privacy come to the surface in the thresholds and interstices between physical space (which are themselves value-neutral and do not automatically imply privacy) and the apprehension of these spaces by each individual author (who imbued these spaces with their own interpretation). In the documents analyzed below, spaces of privacy emerge in opposition to, for example, spaces accessible to the public or spaces that were commonly shared and could not be protected.

In this paper, the main focus will be primarily on 'egodocuments', by which I mean 'texts written by an author who writes about him or herself' and which will be examined to find early modern personal expressions of spatial privacy. ${ }^{9}$

8 In my analysis, I use as guidance the heuristic zones of privacy as proposed by Mette Birkedal Bruun: mind/soul, body, bedroom/chamber, home/household, community, and state/society. See Mette Birkedal Bruun, 'The centre for privacy studies work method, online ed., https://teol.ku.dk/ privacy/research/work-method/privacy_work_method.pdf/PRIVACY_Work_Method_Acces.pdf, accessed 8 January 2020.

9 Jacob Presser, 'Memoires als geschiedbron', in: Herman Richard Hoetink et al. (eds.), Algemene Winkler Prins Encyclopedie, Vol. 8 (Amsterdam 1958). On the historical background of Presser's use of the term, see also Rudolf Dekker, 'Jacques Presser's heritage. Egodocuments in the study of history', $M e$ moria y Civilizacion 5 (2002) 13-37, 25 and Kaspar von Greyerz, 'Ego-documents. The last word?', German History 28:3 (2010) 273-282, 277-278. On Dutch egodocuments, see the work of Rudolf Dekker and Arianne Baggerman (eds.), Egodocumenten van Nederlanders uit de zestiende tot begin negentiende eeuw. Repertorium (Amsterdam 2016); Rudolf Dekker, 'Introduction', in: Rudolf Dekker (ed.) Egodocuments and history. Autobiographical writings in its social context since the middle ages (Hilversum 2002) 7-20; Rudolf Dekker, 'Ego-documents in the Netherlands 1500-1814', Dutch Crossing: A Journal of Low Countries Studies 39 (1989) 61-71. 
The term 'egodocument' includes diaries, letters, travel journals, memoirs, and autobiographies and functions as a useful toolkit to refer to a wealth of historical material containing an individuals' expressions, understandings, and representations of their own ideas. ${ }^{10}$ Other types of sources will also be used to complement the analysis. It is important to note at the outset that the different authors of egodocuments chose to focus on topics that appealed to their own personal interests and did not depict all the aspects of their life. This perspective makes these sources particularly important for understanding their authors' own ideas regarding spatial privacy, of which we will examine a few examples.

\section{Spaces of privacy in the architecture of the home}

The sixteenth century saw dramatic changes in the structure of houses, irrespective of whether it was a palace or a smaller dwelling. Historians of architecture link this development to a growing concern for privacy in seventeenth-century houses in the United Provinces. A theoretical basis for this innovation was provided by the mathematician, physicist, and architect Simon Stevin (1548-1620) around 16oo. ${ }^{11}$ In his unfinished essay De Huysbou (which presented an approach to the family home that was quite innovative for its time), Stevin sketched an idealized layout of a household based on degrees of accessibility, thereby limiting strangers' access to certain spaces within the house. The underlying idea was that members of the family and visitors should not intermix unless explicitly invited to do so. Consequently, members of the household had a heightened degree of freedom when inside the house.

10 See the discussion of the term 'autobiography' in Sidonie Smith and Julia Watson, A guide for interpreting life narratives, $2^{\text {nd }}$ ed. (Minneapolis 2010) 1-4. The limitations of egodocuments are wellknown, as not always providing the most reliable information. See the works of Dekker mentioned above.

11 Simon Stevin (1548-1620) came from Bruges in the southern Netherlands and was an important mathematician who worked with, among others, Prince Mauritz of Orange (1567-1625), Stadtholder of Holland. For Stevin's ideas about the space of the household, see Charles van den Heuvel, 'De Huysbou'. A reconstruction of an unfinished treatise on architecture, town planning and civil engineering by Simon Stevin (Amsterdam 2005). For the emergence of privacy in Dutch architecture and Stevin's take on it, see: Heidi de Mare, Huiselijke taferelen. De veranderende rol van het beeld in de Gouden Eeuw (Nijmegen 2012). 


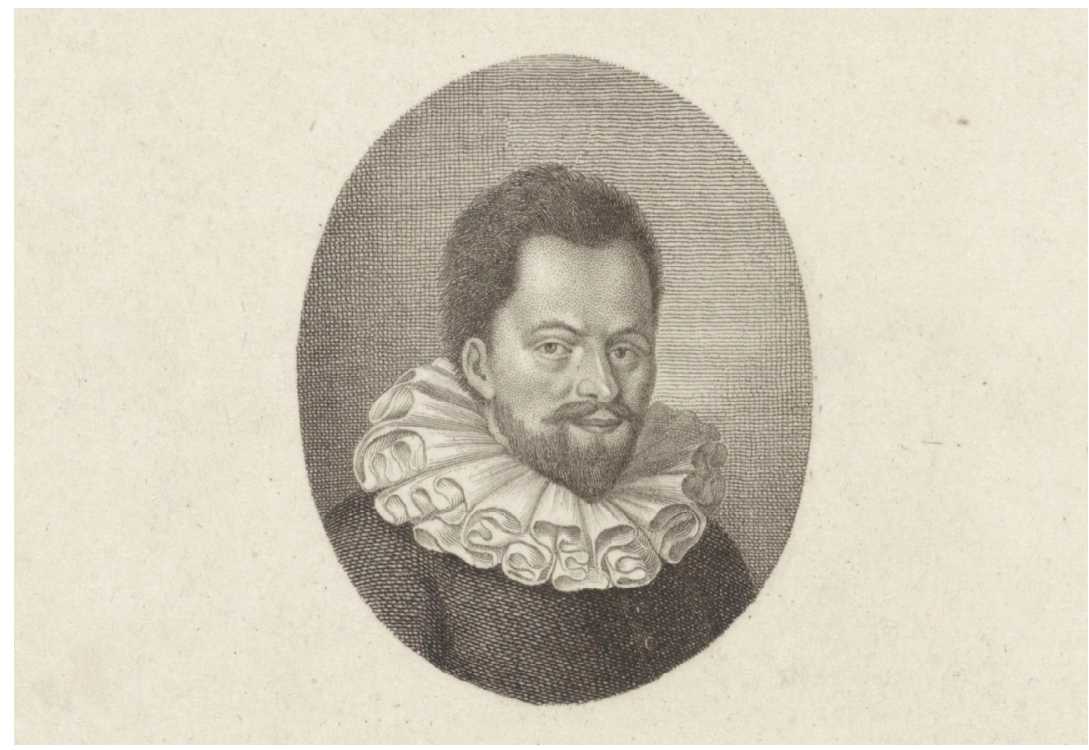

Illustration 1 An inspired portrait of Simon Stevin by Philippus Velijn, 1821 (source: Rijksmuseum Amsterdam, RP-P-1907-3467.)

In his work, Stevin outlined rooms with special functions: cleaning room, bedroom, office/study (comptoir), and many others. According to Stevin, the ideal house should have two sets of stairs, one for the male head of the family and the other for his wife, children, and servants. The rooms should have doors with locks. ${ }^{12}$ The toilet (the privy) should also have a door in order to prevent the odour of bodily functions from penetrating the other parts of the house. ${ }^{13}$ Two sets of keys were to be made, one for the head of the house and one for his wife. In addition to these keys (which should unlock all the doors in the house), the head of the family was to have a separate key to his office space, and his wife was to have her own set for the linen and the clothing chests. ${ }^{14}$ For Stevin, the office space was a private place for the husband, whereas the wife enjoyed only private storage.

Stevin's ideas quickly became well known in the United Provinces; in fact, around the mid-seventeenth century, houses were built or renovated along lines influenced by his suggestions, resulting in what 
can be defined as 'chamberization. ${ }^{15}$ The bedroom (illustration 2 ) developed out of a curtained main room with a bed placed inside it. ${ }^{16}$ Curtains provided privacy and allowed others to pass by without disturbing the person inside. In the same way, the library seems to have developed out of the bookcase, and the dining room appears to have extended out from the kitchen. These developments indicate that functions performed by furniture could eventually evolve into the separate rooms dedicated to specific purposes that we know today. Furniture itself also advanced and became more elaborate. For example, the writing desk and the locked door became common features in houses. ${ }^{17}$ The evolution of furniture into specialized rooms within the Dutch context was gradual and slow, and the first ones to benefit from it were the elite classes rather than the middling sorts.

An important innovation was the passageway or corridor situated in the middle of the house. Initially, this room - called voorsael or hall by Stevin - was meant to be a room from which one could enter four other separate rooms as well as serve as a living room. Stevin was the first to mention a space dedicated exclusively to receiving visitors. From the hall, one could enter an individual room that could be closed by its own door. ${ }^{18}$ The corridor eliminated the need for passing through various rooms, thereby effectively creating a closed and private space. ${ }^{19}$ No longer was it necessary to walk through one chamber to enter into the next one. In many canal houses in Amsterdam, the hall was usually situated one floor above the ground floor in order to prevent strangers at street level from peeking in. The financial cost of such a novelty was, however, not negligible, since the placement of a corridor occupied extra space and cost more money. Privacy was expensive and was therefore a commodity only available to those who could pay for it.

15 See for example Michelle Perrot, Histoire de chambres (Paris 2009).

16 Robin Evans, 'Figures, doors, and passages'. (1978), in: Idem, Translations from drawing to building and other essays (London 1997) 55-91

17 Thera Wijsenbeek-Olthuis, Achter de gevels van Delft (Amsterdam 1987).

18 On Stevin's idea of the voorsael, see Martha Hollander, Structures of space and society in the seventeenth-century Dutch interior (Doctoral dissertation; University of California at Berkeley 1990) 39-40.

19 On the corridor, see Evans, 'Figures, doors, and passages', 7o; John Summerson (ed.), The book of architecture by John Thorpe (Glasgow 1966). For a more recent study which builds upon previous scholarship, see Judith Flanders, The making of home (London 2014) 50. On architectural developments in Amsterdam, see Koen Ottenheym, Paul Rosenberg and Niek Smit, Hendrick de Keyser. Architectura Moderna. Moderne bouwkunst in Amsterdam $1600-1625$ (Amsterdam 2008). 


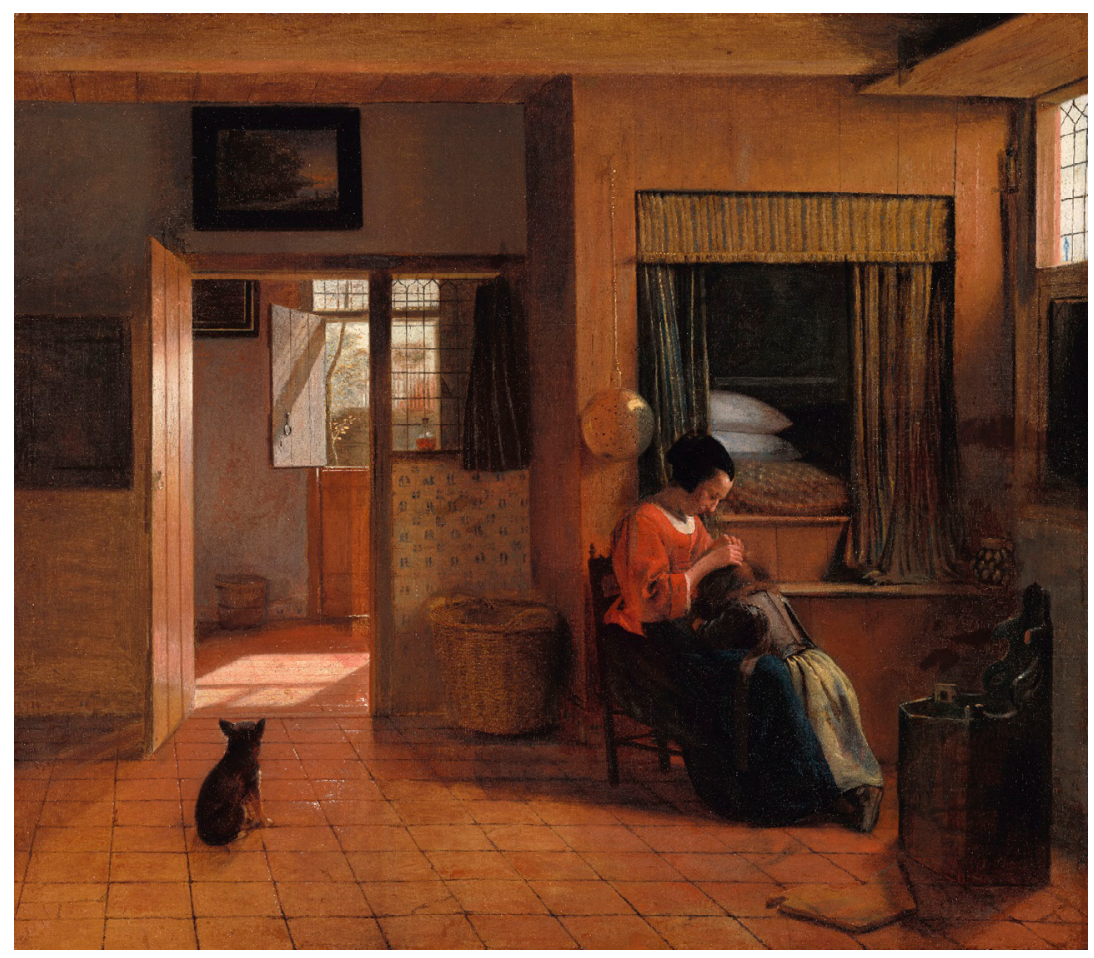

Illustration 2 Example of a bedroom in A mother delousing her child's hair by Pieter de Hooch (source: Rijksmuseum Amsterdam, SK-C-149.)

\section{Spaces of privacy in the diary of schoolmaster David Beck}

David Beck (1594-1634), a poet and schoolmaster from Cologne, kept a diary during 1624, when he lived in The Hague. ${ }^{2 \circ} \mathrm{A}$ man who was part of the middling sorts in Dutch society, Beck kept this diary on a daily basis. Unlike most diaries written by Beck's contemporaries, his is very detailed. It offers a comprehensive account of the internal division of his house in The Hague. We learn, for example, that he had a study with books, just as Stevin had suggested in his work. The Dutch word used by Beck was comptoir or, in Beck's spelling, 'contoor', by which he meant a

20 Jeroen Blaak, 'Mirror of literacy. Reading and writing in the diary (1624) of David Beck', in: Idem, Reading and writing in early modern Dutch diaries (Leiden and Boston 2009) 41-111. The original text is published in full in David Beck, Spiegel van mijn leven. Haags dagboek 1624, ed. Sv. E. Veldhuijzen (Hilversum 1993). Two additional diaries of his were published in David Beck, Mijn voornaamste daden en ontmoetingen. Dagboek van David Beck, Arnhem 1627-1628, ed. Jeroen Blaak (Hilversum 2014). 
private office. ${ }^{21}$ Bearing in mind that the original meaning of the word comptoir was a money chest, we see that by the time Beck was writing, the meaning of the word had evolved from denoting a chest to an entire room. It was a place where he could read and write at his leisure. It was a private place, open only to (mostly) male friends whom he received there to talk about books, art, news, and suchlike.

On 2 December 1624, Beck wrote: 'From mid-day I was reading (without eating) for 1.5 hours in my study the Bibliotheque francoise by A[ntoine, M.G.] du Verdier.'. ${ }^{22}$ Four years later, Beck mentioned that ' $[\mathrm{a}] \mathrm{t}$ 7 o'clock Arnhemots Willem came to me for 1 or [2, M.G.] hours to play on [musical, M.G.] instruments. Afterwards I messed about in my study and in my closet and went late to sleep without eating'. ${ }^{23}$ This description exemplifies how the denial of access to unwanted people helped to create a private space of one's own. One could say that Beck negotiated his privacy within his own home by limiting access to his study, his most private zone. Indeed, excluding women and strangers from his comptoir seems to have created a protected space for intellectual exchange between Beck and those he chose to let in.

It is important to note that, to the best of my knowledge, existing egodocuments of early modern Dutch women do not speak of such a comptoir available for their use. This silence does not, however, mean that no woman had such a study of her own; in fact, it is perfectly plausible that some women had access to such a room. In such a case, however, the room would no longer be called a comptoir but a boudoir. Note that in contemporary England, it was also possible for women of high economic standing to keep such a study. ${ }^{24}$

21 The word 'comptoir' appears in the French-Dutch dictionary as a French word meaning a writing or counting table, exchange, or bank. See 'Comptoir', in: Claude Rouxel and François Halma, Dictionnaire nouveau, François \& Flamand (Amsterdam 1686). 'Contoor' is explained as a 'study-room' in: Jeroen Blaak, Geletterde levens. Dagelijks lezen en schrijven in de vroegmoderne tijd in Nederland $1624-1770$ (Hilversum 2004) 89.

22 'Ick las des middags (niet eetende) wel 1 1/2 uijre op mijn Contoor in de Bibliotheque francoise van A. du Verdier'. Beck, Spiegel van mijn leven, 214. The book in question is: Antoine du Verdier, Les Bibliothèques françoises de La Croix du Maine (Lyon 1585). All translations below are mine unless otherwise stated.

23 'Ten 7 uijren quam Arnhemots Willem bij mij 1 uijr of [2] op de instrumenten speelen. Ick futselde daernaer op mijn contoor ende in mijn cas ende ging zonder eten laet slapen'. Beck, Mijn voornaamste daden, 182.

24 See: Karen Stock, 'Bringing the boudoir into the gallery. Florine Stettheimer's "failed" solo exhibition', in: Andrew Graciano (ed.), Exhibiting outside the academy, salon and biennial, 1775-1 999. Alternative venues for display (London and New York 2016) 205-222, here 213. 
On at least one occasion (at a time when he already lived in Arnhem, where he taught at another school), Beck mentions that a woman did enter his study: 'At 7 o'clock I was chatting with d. [Theodosius, M.G.] Calaminus for half an hour, and then I was visited in my study by female cousin Jenneken Mannis and M. van Ommeren, who let me read a pasquil written against him, ${ }^{25}$ Jenneken Mannis was married to Jacob van Ommeren, and Calaminus was a minister and teacher in the Latin School. Similar studies also existed in the houses of Beck's peers where he was frequently invited. On 4 October 1627 , Beck noted: 'Then I was at Menalck's, talking in his study'. ${ }^{26}$ Menalck was a nickname for Herman Breckerveld (1595/6-1673), a painter and glassmaker. ${ }^{27}$ Therefore, the study can be regarded as a private room where particularly close guests would be entertained either through reading, talking, or by playing instruments. This situation further reveals that studies were already in common use in The Hague by 1624 .

At the house of David Beck, the kitchen still fulfilled its historical double function, serving as a place to eat and drink as well as to receive guests. The social centre of his house was organized around the fireplace, and Beck often mentioned in his diary that they 'talked at the fireplace.. ${ }^{28}$

From Beck's writing, we can infer some of his own ideas about privacy. On one occasion, he mentions that he visited a friend in Delft and stayed overnight at his house. The living conditions for a man of middling status, such as Beck or his friend, were such that, on the occasion of the visit, Beck had to share a bed with two other men: '[f]irst we went to bed the three of us at midnight, sleeping together, and lied packed like herrings, especially myself, in the middle. ${ }^{29}$ Such intimacy did not seem to be a privacy concern for him; in fact, sharing a bed was quite usual in the context in which Beck lived. From his account of the incident, there seems to be no indication that he regarded the situation as something extraordinary or felt that his privacy was breached.

25 'Was ten 7 uijren tot d. Calaminij $1 / 2$ uijrken klappen, wert daernaer op mijn contoor besocht van $\mathrm{n}$ [icht] Jenneken Mannis ende M. van Ommeren, die mij liet lesen de pasquil tegen haer gemaeckt'. Entry for 23 January 1628 . Beck, Mijn voornaamste daden, 142.

26 'Daernaer was ick een uijrke bij Menalck op zijn contoorke koutende'. Beck, Mijn voornaamste daden, 109 .

27 Ibid.

28 Beck, Spiegel van mijn leven, 7o. See entry for 1 April 1624.

29 ' $[G]$ ing over midder-nacht eerst met ons zen te Bedde, slapende bij malkanderen ende lagen als heringen gepackt Inzonderheyt ick int midden pacientie'. Beck, Spiegel van mijn leven, 70-71. See entry for 3 April 1624 . 


\section{Constantijn Huygens Jr.'s observations on spatial privacy}

Constantijn Huygens Jr. (1628-1697), son of Constantijn Huygens (15961687) and Suzanna van Baerle (1599-1637), was a prominent courtier and secretary of the Stadtholder-King William III (1650-1 702). Educated in law at Leiden University, Huygens was an important Dutch politician who kept a journal between 1673 and 1696, where we find traces of his ideas about life at court as well as his personal life, family, sex, and other subjects that we would relate to privacy today.$^{30}$ In contrast to David Beck, Huygens was a member of the elite. His written depiction of spaces of privacy indicates an interest in demonstrating the glamour and privilege that come from having access to the private spaces of people he regarded as important. Unlike the other egodocuments presented in this article, Huygens wrote not only about himself but also about other people.

Huygens recounted in his diary many instances in which his sense of spatial privacy comes to the fore. One example is how he regarded the space of the bedchamber. On 4 January 1689, during the Glorious Revolution, Huygens noted that William III slept at Whitehall in the same room where the son of the deposed king of England, James II (1633$1701)$, had been born six months earlier. ${ }^{31}$ In addition to being interpreted as a political statement, this anecdote can also be construed within the context of Huygens's ideas of privacy. ${ }^{32}$ Huygens, a close affiliate of William III, proudly reported on these particular sleeping quarters, indicating that William III had been welcomed into the inner circle of the deposed Stuart family: by sleeping in this room, William III entered a space reserved for the Stuart dynasty where the Prince of Wales had been born.

30 Huygens's diary was edited in several volumes over the years. See Constantijn Huygens Jr., Journaal van Constantijn Huygens, den zoon, van 21 october 1688 tot 2 sept. 1696, 2 vols (Utrecht 1876-1877); Constantijn Huygens Jr., Journaal van Constantijn Huygens, den zoon, gedurende de veldtochten der jaren 1673 , $1675,1676,1677$ en 1678 (Utrecht 1881); Constantijn Huygens Jr., Journalen van Constantijn Huygens, den zoon. Derde deel (Utrecht 1888). Parts of it were also translated into English. See Constantijn Huygens Jr., The diary of Constantijn Huygens Jr. Secretary to Stadholder-King William of Orange, ed. and transl. by Rudolf Dekker (Amsterdam 2015). For a current interpretation of his journal, see Rudolf Dekker, Family, culture and society in the diary of Constantijn Huygens Jr, secretary to Stadholder-King William of Orange (Leiden and Boston 2013), Idem, The diary of Constantijn Huygens Jr, secretary to Stadholder-King William of Orange (Amsterdam 2015) and Idem, Constantijn Huygens jr. en de uitvinding van het moderne dagboek. Observaties van een zeventiende-eeuwse wereldbeschouwer, $2^{\text {nd }}$ extended edition (Amsterdam 2015). The extent and scope of Huygens's journal makes it comparable to the diary of Samuel Pepys (1633-1703), his contemporary from England who also wrote in a similar style. See Robert Latham and William Matthews (eds.), The diary of Samuel Pepys. A new and complete transcription, 11 vols (Berkeley 200o).

31 The son of James II mentioned by Huygens was James Francis Stuart, born on 10 June 1688.

Dekker, Family, culture and society, 38 . 


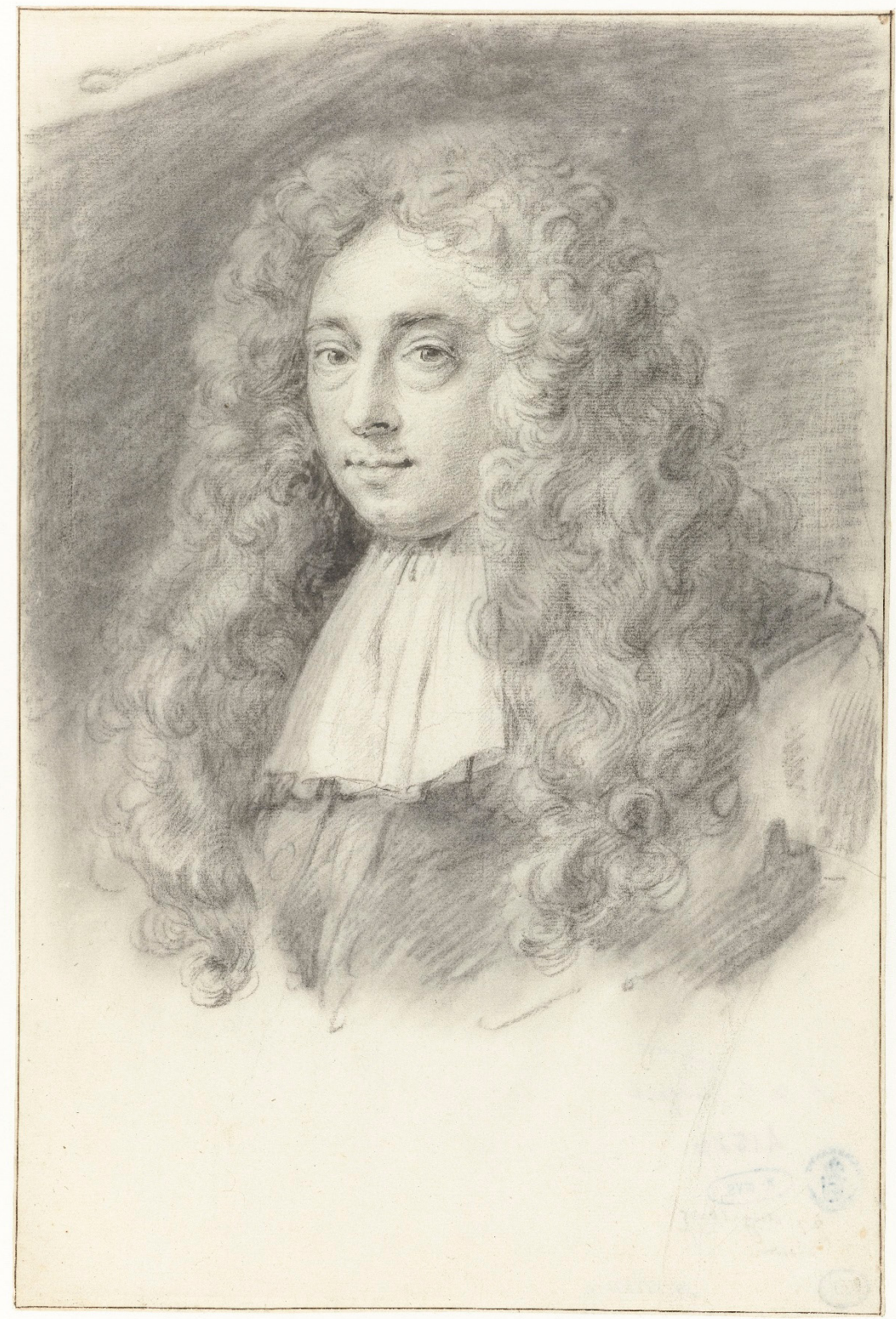

Illustration 3 Self-portrait (?) of Constantijn Huygens Jr, Constantijn Huygens (II) (?), 1685. (source: Rijksmuseum Amsterdam, RP-T-1888-A-1520.)

Huygens also expressed curiosity about what could transpire behind walls where he was not welcomed in. This interest is particularly evident in a diary entry from 27 October 1682 , where he recounted how 
he had asked the valet of the king 'what [Johan, M.G.] Van Dorp was doing during such long and private visits to the king, which, as I had seen had been going on for some time, he staying inside sometimes for half an hour'. ${ }^{33}$ In response, the valet simply reassured the curious Huygens that none of what he had been implying had come to pass. ${ }^{34}$ This passage demonstrates that Huygens seemed both curious and unhappy about not having access to this particular space, and that he suspected the actions happening beyond his reach. Interestingly, the passage also demonstrates that the valet of the king was the instrument that enabled spatial privacy in this particular instance.

In his diary, Huygens also noted down the names of people whom he welcomed into his private space. During his stay in England in the summer of 1689 , he mentioned that Stanley and Dijkvelt 'dronck choccolate' at his place on 28 and 29 July respectively. ${ }^{35}$ Another similar visit was mentioned during his stay in Den Bosch on 1 June 1691 when 'De Langhe, Schuyl and Amelisweer came [over, M.G.] in the evening, while we [probably his household, M.G.] sat at the table, and did not let me go sleep. ${ }^{36}$

Huygens further reported how, together with the nobleman Jan van der Does van Bergesteyn (d. 1704) and the painter Frans van Son (Sonnius) (?-?), he visited the rooms under the cabinet of William III in the Whitehall on 22 January 1690 where they looked at four or five books, including works by Holbein and Leonardo da Vinci. ${ }^{37}$ Around one-anda-half years later, on 9 June 1691 during his stay in Anderlecht near Brussels, Huygens recounted enthusiastically that before midday, news came out the antechamber of the King:

that in the quarter of the court, Mylord Portland, in the furthest chamber that overlooked the garden, Erasmus had previously stayed $[\ldots]^{38}$ The

33 Ibid., 13 o.

34 For more on sexuality, see Rudolf Dekker, 'Sexuality, elites, and court life in the late seventeenth century. The diaries of Constantijn Huygens, Jr.', Eighteenth-Century Life 23 (1999) 94-109.

35 Ibid.

36 'Savonts quam de Langhe, Schuyl en Amelisweert, dewijl wij aen tafel saten, en beletteden mij een tijdtlang van te gaen slaepen'. See Ibid. Entry for 1 June 1691. Online ed, https://www.dbnl.org/tekst/ huygoo7jouro2_01/huygoo7jouro2_01_oo34.php, accessed on 1 June 2019.

37 'Was smergens met Berghesteyn en Sonnius in de camers onder de Con. cabinet, daer wij vier of 5 boecken met teeckeninghen saghen, onder andere die van Holbeen en van Lionardo da Vinci'. See Ibid. Entry for 22 January 169o. https://www.dbnl.org/tekst/huygoo7jouro2_01/huygoo7jouro2_01_0017. php, online ed., accessed 1 June 2019.

38 Hans Willem Bentinck (1656-1702), the Earl of Portland, was one of closest associates of William III. See: Marion Ethel Grew, William Bentinck and William III (Prince of Orange). The life of Bentinck Earl of Portland from the Welbeck correspondence (London 1924). 
house belonged to Jan Baptist Charles van der Gote, Lord of Bellaert, and in various places on the walls there were metal wall clamps in the shape of ciphers indicating the year 1515. It was said that Erasmus once upon a time had lived there in order to recover from a sickness, by changing the air, and referred to Anderlech[t, M.G.] as Anderclacht. ${ }^{39}$

For Huygens and his entourage, the idea of living in Erasmus's chamber seems to have been important. His writing offers the impression that Huygens was excited about this proximity. The spatial references used by Huygens therefore seem to indicate the closeness he had with his associates. Many of them - such as Bergesteyn and Sonnius - are mentioned on many occasions throughout his diary.

As we can see, when Huygens wrote about spatial privacy, he was particularly concerned with privileged spaces of people of the higher echelons. Access to spaces of privacy for him seems to be connected to status and social importance, a point that is starkly demonstrated by the anecdote above about Erasmus's chamber. He also seems to have had little patience for being denied access to the private space of the king, but having no power to control the situation, he resorted to expressing his curiosity and frustration towards what was happening inside beyond his reach.

\section{Spaces for feeling happy and sad for Maria de Neufville of Amsterdam}

This section is dedicated to a discussion of the work entitled Story of My Sad Life (Verhaal van myn droevig leeven) by Maria de Neufville (16991779). This work will be discussed in greater detail than the two cases presented above because it allows us to examine how the need for privacy was negotiated between bodies occupying spaces within the home and in the community. $4^{\circ}$

39 ' [... ] dat in het quartier van 't Hoff, daer Myl. Portland logeerde, in de uyterste camer, die op den thuyn uytsagh, Erasmus eertijts gelogeert hadde [...] Het huys hoorde aen Jan Bapts Charles van der Gote, Heer van Bellaert, en stondt daer op verscheydene plaetsen op de mueren ijsers als anckers, representerende 1515. Men seyde, dat Erasmus daer gewoont hadde, om uyt een sieckte komende van lucht te veranderen en Anderlech[t] Anderclacht genoemt hadde.' 'Anderclacht' means 'another complaint'. Huygens Jr.,Journaal, see entry for 9June 1691. https://www.dbnl.org/tekst/huygoo7jouro2_01/ huygoo7jouro2_01_o034.php, online ed, accessed 1 June 2019. 40 Maria de Neufville, Verhaal van myn droevig leeven, ed. by Tony Lindijer (Hilversum 1997). 
Maria de Neufville was born in Amsterdam on 4 February 1699 to a family of Mennonite traders. Her father Isaak de Neufville (1658-1710) and her mother Maria Grijspeert (1667-1726) were married in 1685 . Her mother's family fled from Flanders during the persecutions of the sixteenth century, settling initially in Haarlem, and her father also came from a family of Walloon immigrants. Amsterdam, a city convenient for traders, was the destination of the newlyweds. They lived in the 'De Oraigne boom' or 'de Kroon' house in Warmoesstraat in Amsterdam, an area with a large Mennonite population. ${ }^{41}$ An Amsterdammer by birth, Maria spent most of her life within the Mennonite milieu of the city. ${ }^{42}$ Although later in life she relocated several times to live in smaller cities, it would be safe to assume that her perception of personal spaces and privacy was influenced by her family in Amsterdam.

At the age of eleven, Maria lost her father. She lived together with her strict mother and her five siblings Mattheus, Isaak, Pieter, Catharina (Katie), and Jan Isaac. The third child out of six, Maria helped her mother to raise her younger siblings. After the death of her mother, she remained in the family home and, following the death of her brother Isaak's wife, moved in with him to assist him in raising his young daughter Maria Petronella (who would go on to become her closest family member) and in the running of his shop. As the years went by, many of her relatives - including her brothers, cousins, and their wives - died, leaving Maria grief-stricken. Towards the end of her life, Maria wrote that she was lonely, with only distant family members alive. ${ }^{43}$

\footnotetext{
41 For biographical and additional information in my analysis, I used the well-transcribed and wellresearched edition of the Story by Tony Lindijer. Ibid., 7-15.

42 For an accessible overview of Mennonites in the United Provinces, see Willem Frijhoff and Marijke Spies, 1650. Hard-won unity (Assen 2004) 399-409. On Mennonites in Amsterdam, see Troy Osborne, 'Mennonites and violence in early modern Amsterdam', Church History and Religious Culture 95:4 (2015) 477-494; Mary Sprunger, 'Deaconesses, fishwives, crooks and prophetesses. Mennonite image and reality in golden age Amsterdam', in: Mirjam van Veen, Piet Visser and Gary R. Waite (eds.), Sisters. Myth and reality of Anabaptist, Mennonite, and Doopsgezind women ca. 1525-1 900 (Leiden and Boston 2014) 169-185; Mary Sprunger, 'Why the rich got Mennonite. Church membership, status and wealth in golden age Amsterdam', Journal of Mennonite Studies 27 (2009) 41-59. Two examples of scholarship on particular Mennonites are Keith Sprunger, 'Frans Houttuyn, Amsterdam bookseller. Preaching, publishing and the Mennonite Enlightenment', Mennonite Quarterly Review 78:2 (2004) 165-184 and Keith Sprunger, 'Jan Theunisz of Amsterdam (1569-1638). Mennonite printer, pamphleteer, renaissance man', Mennonite Quarterly Review 68:4 (1994) 437-46o.

43 The editor of the Story informs the reader that various papers of Maria de Neufville were sent to her nephews in Amsterdam by someone who found them at her home in Mijdrecht after her death. The papers eventually ended up in the Amsterdam City Archives together with numerous other documents related to the family. Maria de Neufville's writings can be found under shelf-mark 1179-1181.
} 
The Story is a relatively short piece in which the eighty-year-old Maria poured her heart out on paper in her own hand about what she perceived as the endless troubles and sorrows that she experienced during her long life. In this brief autobiographical essay, 'sadness' is the leitmotif - the Story is the cry of a person who, at the moment of writing, felt that the entirety of her life had consisted of suffering. ${ }^{44}$ Given the stereotype of the obedient and submissive Mennonite woman, Maria's ceaseless complaining about her sorrows in her work appears to contradict both gender and societal expectations. ${ }^{45}$ While it is possible that Maria's text might have been aimed at her family, it could also have been her own way of coping with the pain that she felt she had endured during her life. In other words, her text can be interpreted as her personal attempt to open up her private feelings, an endeavour to set the record straight, perhaps with God, at the very end of her life.

Though her written account is the only imperfect window we have into Maria's thoughts and feelings, the text does describe what we would today consider to be deeply personal topics. She wrote about how she never married and had no children, how she felt lonely and abandoned, and how her closest relatives who were still alive at the time of writing the text were her nephews. As a self-portrait of her feelings, Maria's work indirectly helps to reveal notions of privacy that were prevalent during her time. Although the Story frequently features death, the use of the theme in the work was not new; in fact, the topic was very prominent in egodocuments written in Amsterdam during that period. For instance, the poet and painter Jan Sijwertsz Kolm (1589-1637) mourned the death of his little son Sijwerts by painting his image in his memoirs and composing a small poem. ${ }^{46}$ Elisabeth van der Woude recorded in her diary that the death of her 'beloved father Harman Hartman van der Woude' on 8 January 1677 brought 'great sadness' to herself and her

45 Michael Driedger, 'Mennonites, gender and the rise of civil society in the Dutch enlightenment', in: Van Veen, Visser and Waite (eds.), Sisters, 229-250, 235.

46 Mieke. B. Smits-Veldt, 'De nalatenschap van Jan Sijwertsz Kolm (1589-1637). Het gezicht van een Amsterdamse rederijker', Literatuur 8 (1991) 93-102, 98. See also Truusje Goedings, 'Een bijzonder rederijkersmanuscript. Het Ghedenckboeck van de schilder Jan Sieuwertsz Kolm (1590-1637)', Amstelodamum 85:5 (1998) 194-209. The original document is located in: CAA (City Archives Amsterdam), 'Ghedenckboeck waerin state geteeckent, gerijmt en geschreven en gecoleurt alles wat hier in op 't paier vertoont wert is gedaen deur mij Jan Sywertsz Kolm ghebooren tot Amsterdam', archive number 15030, inventory number $56904,52046,77884$. 


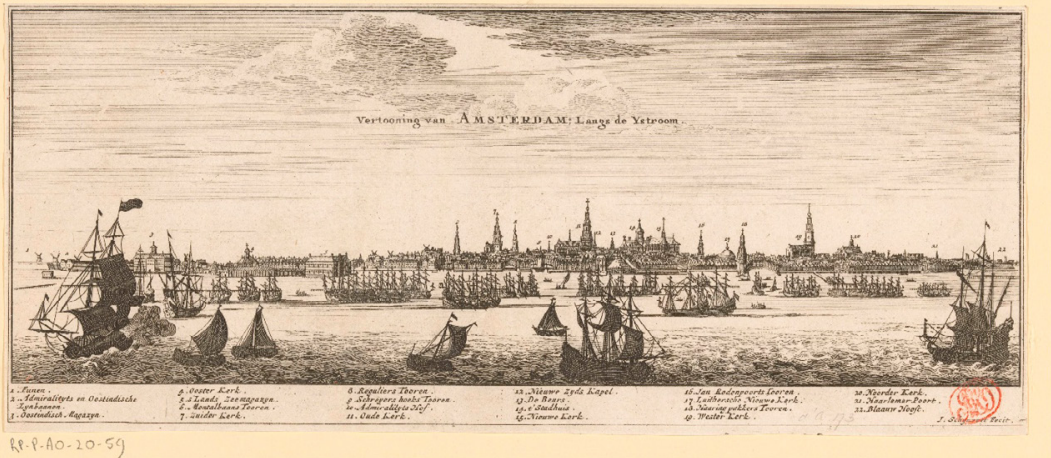

Illustration 4 View of Amsterdam, Jacobus Schijnvoet, ca. 1713-1751 (source: Rijksmuseum Amsterdam, RP-P-AO-20-59.)

siblings. ${ }^{47}$ Jacob Bicker Raye noted almost every death of fellow Amsterdammers in his diary without showing much emotion. ${ }^{8}$ In Maria's Sto$r y$, deaths were usually reported in chronological order, although only those related to her family were mentioned.

Maria began her text by observing that she had an unhappy childhood because her father, with whom she had frequent arguments, died when she was only ten years old. ${ }^{49}$ She noted that this death not only made her mother's household an unhappy one to live in, but also, and more importantly, it was the first among many that were to come. Maria wrote that a few years after the death of her father, '[her, M.G.] uncle van Beeck died', noting that he loved [her, M.G.] so much'. Eighty years old at the time she was writing, Maria wrote about this loss as strongly as if she were her fifteen-year-old self when the death happened in $1714 \cdot \cdot^{50}$ Maria wrote that for a little while afterwards, she felt well. ${ }^{.1}$ 'But that did not last long, as [her, M.G.] mother

47 S.P. L'Honoré (ed.), 'Eene hollandsche jonge dame aan de Oyapock in 1677. Dagboek van Elisabeth van derWoude', Bijdragen en Mededeelingen van het Historisch Genootschap 49 (1928) 214-236, 224. For a new version, see Elisabeth van der Woude, Elisabeth van der Woude. Memorije van 't geen bij mijn tijt is voorgevallen: met het opzienbarende verslag van haar reis naar de Wilde Kust 1676-1677, ed. by Kim Isolde Muller (Amsterdam 2001). For more on Elisabeth van der Woude, see Marijke Barend-van Haeften, 'Een mislukte kolonisatie aan de Oyapoc door vrouwenogen bezien. Het verslag van een reis naar de Wilde Kust door Elisabeth van der Woude (1676-1677)', De Zeventiende Eeuw 21:1 (2005) 91-98.

48 Leonie van Nierop, 'Het dagboek van Jacob Bicker Raye (1732-1772), Jaarboek Amstelodamum 32 (1934) 119-143. It is not my goal here to engage in discussion on early modern understanding of emotions, but the interested reader can refer to: Monique Scheer, 'Are emotions a kind of practice (and is that what makes them have a history)? A Bourdieuian approach to understanding emotion', History \& Theory 51:2 (2012) 193-220; Rob Boddice, The history of emotions (Manchester 2018).

49 According to the editor of the Story, Maria was in fact eleven years old. See: De Neufville, Verhaal, 34.

5 o Ibid., 36 .

51 Ibid., 39-44. 
was sick and swelled up, so fat [...] that we all thought she would die..$^{2}$ Maria's mother did eventually die in 1726 , after a long illness.

Maria wrote that during her childhood, her mother initially tried to educate her with beatings but eventually sent her to school, where she had some positive experiences with the Mennonite schoolmistress De Haan. After some time, Maria's mother wanted her to return home, promising a softer treatment, a proposition to which she acquiesced. From that moment on, Maria's relationship with her mother, a 'God-fearing woman', improved, and she became an important part of the family, helping her mother with the upbringing of her younger siblings. Maria wrote that she had good moments of 'plaisire' with her sister, adding that '[her, M.G.] sister Anna was indeed [her, M.G.] most beloved of all [her, M.G.] brothers and sisters' and concluding with a note of sadness about Anna's death: 'she doesn't hear it now'.53 Anna was married to Jacobus van der Hoop and had two daughters, who also brought joy to Maria.

For Maria, however, happiness was often intertwined with sadness. For instance, she wrote that the marriage of her second brother Isaac to their cousin Petronella - a supposedly happy event for Maria and the family - only brought her little joy, and Maria remained 'sickly' (sickelijk). She confessed that she was affected more by sadness than by happiness, explaining 'that is often like that when the person is sickly'. ${ }^{44}$ Maria also mentioned that although she travelled together with her sister Anna to many different places 'outside', she remained 'apathetic' (lustloos), ${ }^{55}$ adding that when she was young, she was small in size and had a difficult personality.

Maria's writing makes it clear that she had a difficult time enjoying herself. She uses words such as 'sickly' and 'apathetic' to describe herself and recounts the story of the trauma brought about by her mother's beatings. Maria does mention moments of happiness, especially the 'plaisire' that she had enjoyed with her sister Anna and her daughters. However, the overall self-image that Maria conjures through her writing is that of a person who is not at ease with herself. ${ }^{6}$

In the text, there appears to be a correlation between Maria's state of mind and her physical location. She explicitly mentioned that she did not feel well when she was outside the house, writing that she felt secure and

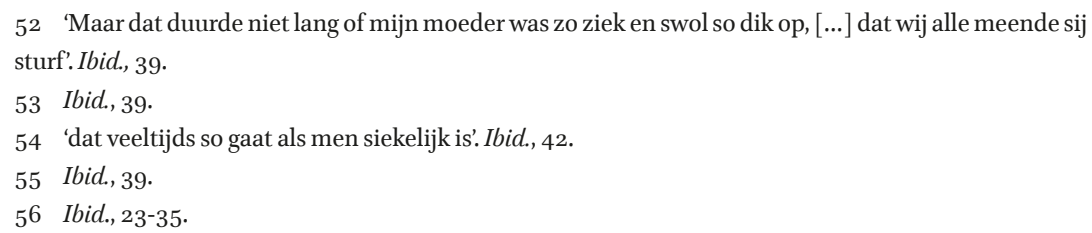


more at ease 'at home' but became unhappy when she was sent outside to clean. ${ }^{57}$ As a teenager, she preferred to stay with a maid at home while her brothers were outside, though she preferred the 'peace' (rust). ${ }^{58} \mathrm{~A}$ telling example of the relationship between Maria's feelings and her physical location is the story of a trip she made to England in 1725 . The departure of her eldest brother Mattheus to that country at the age of 36 had 'provided new sadness. ${ }^{59}$ Maria's mother, seeing her daughter suffering from the departure of her brother, came up with a creative solution to cure Maria's sadness: she was sent to visit Mattheus in England together with her brothers Pieter, Jan Isaak, and his wife. However, Maria wrote that after she went outside, ' $[\mathrm{I}]$ returned home in a worse state than I was before I left. ${ }^{\circ} \circ$

In 1731, Isaak's wife Petronella passed away. ${ }^{61}$ Although Maria was very sad about this loss, it brought her an unexpected consolation. Isaak and Petronella had lived together with their child in Isaak's shop located on the Heerengracht in Amsterdam. Upon the death of his wife, Isaak invited Maria to live 'with him in [his] house. ${ }^{62}$ Caring for her brother's household seems to have been a positive experience for Maria. She wrote:

But then the joy of my life arrived, which was also the only time of cheerfulness. And even though there had been deaths in between, because I now had my health restored again, I could better cope and also got twelve suitors [for my hand, M.G.], one after another. ${ }^{63}$

But death struck again in 1738 , and this time it was the turn of her brother Isaak. Maria observed: 'In the meantime, my brother the widower died, which caused me sadness once again, because I had lived with him for so long and was taking care of his household as my own, ${ }^{64}$

\footnotetext{
57 Ibid., 36.

58 Ibid.

59 Ibid., 42.

60 'ik kwam erger thuys als doe ik uyt ging'. Ibid., 42.

61 Ibid., 48.

62 'bij hem ter wooning hebben'. Ibid.; Lotte van de Pol, The burgher and the whore. Prostitution in early modern Amsterdam, transl. by Liz Waters (Oxford 2011) 57. The Heerengracht also attracted the attention of painters who immortalized its view. See Wolfgang Stechow, 'Jan Wijnants. View of the Heerengracht, Amsterdam', The Bulletin of the Cleveland Museum of Art 52:10 (1965) 164-173.

63 'Maar doe kwam de vreugd van mijn levenstijd aan, dat ook de eenigste tijd is geweest van vrolijkheyd. En of daar al sterfgevalle tusse beyde kwaame, dog doordat ik mijn gesond heyd nu volkome weder had, kon ik die beter versetten en kreeg doe ook wel twalf pretendents, de eene voor en de andere na'. De Neufville, Verhaal, 48-49.

64 'Ondertusse kwam myn broer de weeuwenaar te sterve, dat mijn al weer droefheyd veroorzaakte omdat ik so lang bij hem gewoond had en sijn huyshouwe waargenoome als eyge'. Ibid., 56 .
} 
There are, however, other examples in the text where Maria seems to enjoy life outside the boundaries of the house. She wrote, for instance, that when she moved to Arnhem, despite some 'instances of death' from time to time, her 'health was restored to full'. She attended various 'societies' ${ }^{\prime}$. and even enjoyed the attention of twelve suitors, all of whom she refused at the time only to regret this decision later. ${ }^{66}$ Another instance of Maria being well outside her personal space is an episode from 1734 in which Maria recounted that 'that nasty death came again and took my brother van der Hoop in its claws, ${ }^{67}$ Van der Hoop was the husband of her sister Anna and therefore Maria's brother-in-law. Following Van der Hoop's death, Maria and Anna moved together to Rotterdam where his family resided. Despite the move, Maria wrote that she felt well and was able to care for her widowed sister. ${ }^{68}$

Maria shared an intimate relationship with her cousin Abraham Bierens, who was an important source of consolation for her on the occasion of the demise of her brothers Pieter and Isaak, as well as her brother-in-law Jan Isaak. Maria wrote that she felt 'detached from the world', and Abraham showed kindness to her:

Also cousin Bierens consoled me as much as it was in his power. He continued to take care of me to such extent that I believed no one was so taken care of in a hundred nights. If I came home late in the evening, and it was raining or snowing, there was no late evening, whatever weather it was, that he was not immediately with us on the stoop in order to say to me once again good night. And yet I was so detached from the world, when suffering from pneumonia again, he came before my bed and said: 'Should you leave me like that?' To which I replied: 'Yes, I hope I can [go, M.G.] to a better place. ${ }^{69}$

65 Ibid., 48-49.

66 For an overview of the gender politics informing the position of women in early modern society, see Merry Wiesner-Hanks, Women and gender in early modern Europe, $4^{\text {th }}$ ed. (Cambridge 2019); Heide Wunder, She is the sun, he is the moon. Women in early modern Germany, transl. by Thomas Dunlap (Cambridge MA and London 1998). The difference in perception of privacy between men and women in the egodocuments will be the subject of one of my future studies.

67 'Maar wat gebeurder toe, doe kwam die naare dood weer en nam mijn broeder van der Hoop in sijn klaauwe, dat weer een heele bittere slag was voor mijn en voor mijn lieve suster niet minder, die een soon had en nog een kreeg 4 a 6 maanden na haar mans dood'. De Neufville, Verhaal, $50-51$.

68 Rotterdam was an important trading centre for the Atlantic trade and for the Dutch West India Company. See Douglas Catterall, 'Interlopers in an intercultural zone? Early Scots ventures in the Atlantic world, 1630-166o', in: Caroline A. Williams (ed.) Bridging the early modern Atlantic world. People, products, and practices on the move (London and New York 2009) 75-96, 78-87.

69 'Also neef Bierens mijn trooste so veel als in sijn vermogen was. Die mijn so bleef oppassen, dat 
Although it is not explicitly clear whether their relationship was openly sexual, Bierens was welcomed into Maria's bedroom, which seems to indicate that their relationship was very close, and Maria referred to him as her 'bruygom' (bridegroom). This physical closeness also implied a certain emotional intimacy. However, Maria wrote that her happiness was not meant to last:

Eventually came that unlucky blow that has never gone away from my thoughts [since, M.G.], and never will. And the most cruel, merciless death took my bridegroom from me, and in the most bitter way, as it was in the same time that I indeed wanted to marry, because my wedding dress was already in the making. Oh death, oh death, what tears and sadness you have cost me! When I still think about that farewell, which was not once but ten times, then the deepest insides of my soul shake. ${ }^{70}$

Abraham's death was devastating for Maria, and her interpretation at the moment of writing was that she had lost her last opportunity for personal happiness. Maria wrote that on his deathbed, Bierens had remarked: 'My spirit shall stay with you and will protect you as long as you live, ${ }^{71}$ words which proved to ring true since he left her with an inher-

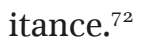

Having remained a spinster after all, Maria lived with her niece Maria Petronella, who also remained single. ${ }^{73}$ Maria felt a close connection to her niece and proudly noted that on one occasion when Maria Petronella was only seven years old, she had said '[o, M.G.]h aunt, I would wish so much that you would not leave me'. Sometimes, however, Maria Petronella invaded Maria's privacy. An incident recounted by Maria about the time when they lived in the town of Donkervliet offers

ik geloof niemand so opgepast is hondert nagte. Als ik 's avonds laat thuys kwam, en al regende het of sneeude, daar was geen late avond, wat voor weer het was, of hij gelijk met ons aan de stoep om mijn nog eens genagt te seggen. En evenwel was ik so los van de wareld, dak ik eens de pleures had en hij voor mijn bed kwam en sey: "Sout gij mijn so kenne verlate? Daar ik op antwoordde: "Ja, ik hoop dat ik na een beter gang mag"'. De Neufville, Verhaal, $5^{8}$.

70 'Eyndelijk kwam die ongelukkige slag, die nooit uyt mijn gedachte geweest is en daar ook nooit uyt gaan sal. En die allerwreeste, onverbiddelijke dood nam mijn bruygom ook so allerbitterst van mijn of op dieselfde tijd dat ik dogt te trouwe, want mijn bruydskleet was al in de maak. O dood, o dood, wat heeft gij mijn al traane en droefheud gekost! Als ik nog denk om dat afscheyd neeme, dat niet eens was, maar wel tienmaal, dan ontroer ik nog in het binnenste van mijn ziel'. Ibid.

71 'Mijn geest sal bij uw blijve en sal om uw waare so lang als gij leeft'. Ibid.

72 Ibid.

Ibid., 6o-62. 


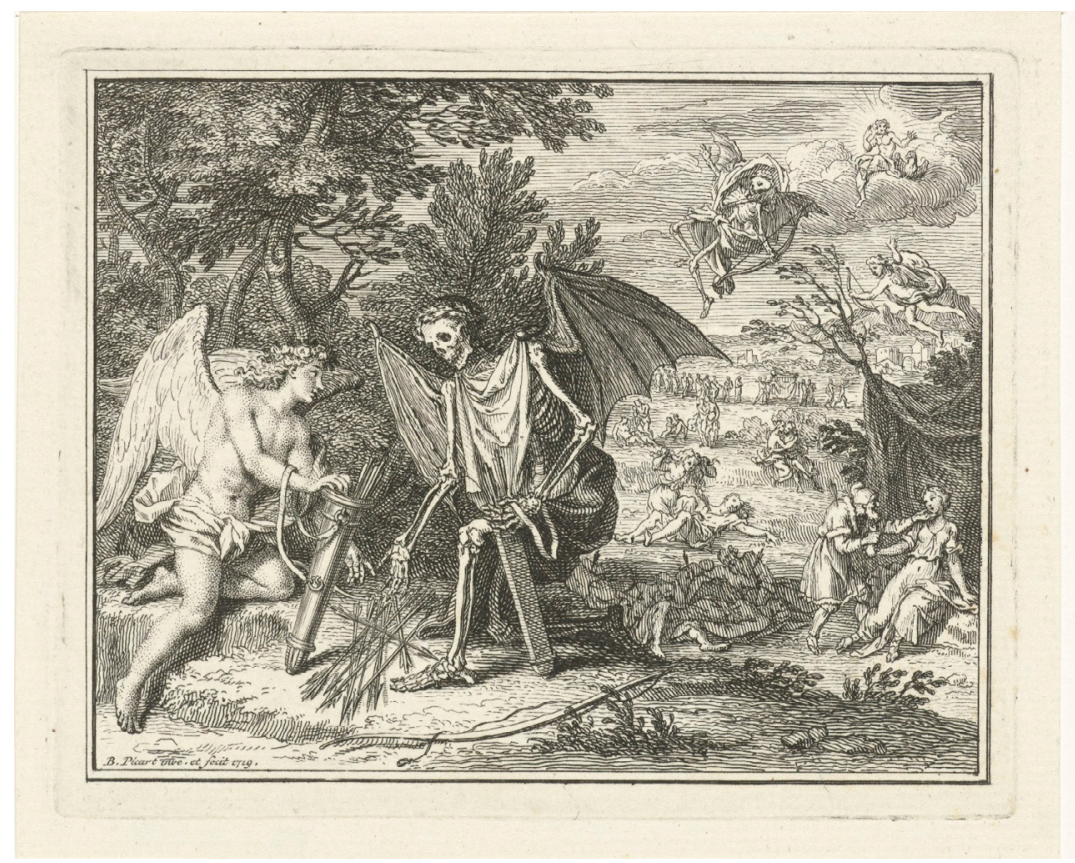

Illustration 5 Allegorical representation with Love and Death, Bernard Picart, 1719 (source: Rijksmuseum Amsterdam, RP-P-AO-20-59.)

another insight into her sense of spatial privacy. Maria wrote that '[her, M.G.] beloved child often got a young woman into the house and a lot of people who were coming out of the ships at half past eleven in order to eat at my place', ${ }^{74}$ adding that she was not happy about it since she preferred silence. ${ }^{75}$ This passage seems to suggest that Maria was not only very protective of her personal space - something which we would call 'private' - but also wanted to prevent people she did not like from entering it.

After the deaths of many close relatives, Maria arrived at the sad realization that there was no one left who cared for her. Maria's emotional state was reflected in her words when she observed that '[e]very day I pour out a flood of tears, and there is nobody who can comfort me. ${ }^{7}$ She withdrew into her mental and emotional world, writing that she began to pray to God daily as He would be her only consolation in her old

74 'En dan kreeg mijn lieve kind ook dikwils jonge juffrouwe te logeren en ook veel mensen die dan te half twaaleve uyt schuyd kwaame om bij mijn te eete, dat mijn veel omslag gaf, wand ik was veel voor de stilte'. Ibid., 75 .

75 Ibid.

76 'Alle dagen stord ik een vloet van traane en daar is niemand, die mijn trooste kan'. Ibid., 88. 
age. Even this comfort was nearly taken away from her when she went almost completely blind, and her suffering was compounded when her beloved niece passed away in 1773:

I had so many little sad things happening, but because there were so many, I would become too tired of writing them here. But more tears were shed and prayers prayed for God Almighty to release my beloved child [her niece Maria Petronella, M.G.] from her thickness, which she had got for several years before her death, but that did not please God..$^{77}$

Maria concluded her autobiographical text with a reference to 'God Almighty' and the hope for happiness in the afterlife. The story of Maria de Neufville implicitly articulates the connections between an individual's emotional state, their body, and their physical space. For Maria, the home and the household were her strongholds, spaces where she was in control, whereas her accounts of being outdoors are invariably portrayed in a more negative light, as in the case of the trip to England. Perhaps that was due to the fact that she was less able to regulate access to herself when she was away from home - in other words, she had less privacy. Maria related physical closeness to a sense of intimacy, a fact demonstrated in the story she told about her fiancé showing her kindness in her bedchamber. Her emotional state was also occasionally influenced by her perceptions of her own body. This effect is illustrated by her stories recounting her traumatic childhood experiences of being beaten by her mother - a stark example of a situation where she was unable to regulate access to herself. Her comments about her personality and physical appearance as a child, as well as in the meaning she attributed to her blindness in her old age, all also indicate that her perception of her body influenced her emotional state. Maria's lack of will to marry implies that she was reluctant to let anyone into her personal space, not only physically but also intellectually and emotionally. Her portrayal of her relationship with her fiancé Bierens is a notable exception to this reluctance, indicating that the couple shared a strong emotional connection as well as a sense of mutual trust.

77 'Wat heb ik nog veel kleynder droefheden gehad, maar dewijl die veele sijn, sou ik te moe worde van al het schrijven. Maar nog veel traane gestord en gebeden gebeden, dat de almagtigen God mijn lieve kind die dikte wilde ontnemen, die sij al eenige jaare voor haar dood kreeg, maar dat heeft God niet behaagt'. Ibid., 9o. 'Thickness' probably refers to an unknown illness, as suggested by the editor of the Story. 


\section{Conclusion}

The egodocuments here discussed provide some evidence of how individuals conceived of their own private spaces, thereby corroborating theoretical developments in early modern architecture (such as those of Stevin). These architectural developments are reflected in the egodocuments presented above. As we have seen in the example of David Beck's diary, he found it important to mention that he had a separate room where he received his (almost exclusively) male guests and gave expression to his own intellectual and musical activities, which were out of reach of anybody else. It can be reasonably conjectured that Beck understood this room (which he called the 'contoor') as his own private space where access was restricted for those he chose to exclude. Beck also offers an insight into the norms of his day regarding the sharing of what we would today consider to be intimate space - such as his bed with his friends and family.

Constantijn Huygens Jr. also referred to his household space as a place where he received his friends and associates, talking about numerous occasions in which he shared a meal with others or discussed current affairs within the premises of his house. Much more outspoken than Beck, Huygens wanted to lift up the curtain on activities that took place at other people's private spaces and to which he had no access. Huygens's curiosity was particularly telling regarding the potentially intimate relations between the king and Johan Van Dorp. The sense of physical proximity to a space once occupied by an individual as greatly renowned as Erasmus made Huygens feel connected to Erasmus's spirit. It also indicates the importance that he attributed to having access to spaces that belonged to people of higher social standing than himself.

Maria de Neufville's Story is rather different in tone compared to the two examples presented above on account of the melancholy and sense of despair that colours the narrative. However, she, too, makes references to spaces that allowed her to, or impeded her from, regulating access to herself. This condition is most clearly expressed in her complaint about her niece's friend who brought strangers into the house to share a meal with them. While this can certainly be interpreted as a sign of social anxiety, it also implies that Maria regarded the household as a space of protection, a safe haven where she wished to live her life without disturbances of any sort. She also offers the reader privileged access to her bedroom where her fiancé offered her consolation, thereby revealing the intimate relationship shared by both. 
This article has shown how early modern notions of privacy can be traced in contemporary egodocuments in relation to space, in particular, in the passages that tell about attempts at regulating access to oneself by controlling access to one's spaces. As the examples cited above have demonstrated, spatial references within the text (based on a careful assessment of both the tone and the context in which the reference appears) offer an insight into what could be regarded as 'private' by the authors.

\section{About the author}

Michaël Green (1980) is professor at the University of Lodz, Poland. He received his $\mathrm{PhD}$ from the University of Groningen in the Netherlands (2013). Since then, he has worked at the University of Geneva, IEGLeibniz Institute for European History, Jagiellonian University of Cracow. He has been researcher at the Centre for Privacy Studies at the University of Copenhagen, and CLUE+ visiting researcher at the Vrije Universiteit Amsterdam. Among his works are The Huguenot Jean Rou (1638-1711). Scholar, Educator, Civil Servant, 2015; Le Grand Tour 1701-1 703. Lettres de Paul Rapin-Thoyras et Henry Bentinck, vicomte Woodstock, à Hans Willem Bentinck (2021). He is also the editor of: M. Yardeni, Minorités et mentalités religieuses en Europe moderne (XVI ${ }^{\text {- }}$ $X V I I I^{e}$ siècle). L'exemple des huguenots (2018), and co-editor together with Mette Birkedal Bruun and Lars Cyril Nørgaard of Early Modern Privacy: Sources and Approaches (2021).

E-mail: michael.green@filhist.uni.lodz.pl 